\title{
Commodification of Identity: Dissecting the Coolie Body in the Indo- Caribbean Diaspora
}

\section{Shehnaz Kabir}

\begin{abstract}
Following the Slavery Abolition Act 1833, the mass labour emigration between 1837 and 1917 became a potent mechanism in the formation of the Indo-Caribbean diaspora. Over time, this "new system of slavery" emanated a new canon of studies related to migration and (re)settlement, the formation of new identities, experiences, and affiliation through assemblages of material. My study will analyse a selected texts from the Indo-Caribbean oeuvre. In the exploration of the intersectionality between migration and materiality, I will posit the significance of human identity and the process of commodification stimulated under the draconian indenture trade. The dehumanized exploitation of these coolies and their descendants is isomorphic of the deeply entrenched binary disposition of privileging the mind over the body, the enlightened over the "primitive", and the West over the East. My paper will engage in the binary prejudice and consequent, the commodification of the Indian coolies during and after the indenture system.

These indentured labourers chose to undertake the hazardous transoceanic journey and forged new yet enduring relationships with their jahaji bhai/bhains (fellow companions on-board). This new-found kinship materialized aboard the inhumane conditions, prompted by the perilous dark waters that surrounded them over the journey of three to four months, continued on the plantation estates. Additionally, my paper shall discuss the way this impactful "coolie odyssey", that took place towards the end of the $19^{\text {th }}$ century from the ports of Bengal via the kala pani to the West Indies, made the Caribbean a microcosm of multicultural societies which underscores the cultural exchanges, the recreation of lifestyle (food, clothing, rites, and rituals) and the adaptive nature of humankind.
\end{abstract}

Keywords: Commodification, Identity, Indo- Caribbean, Coolitude, Indenture.

\section{Recruitment of Coolies}

Western society possesses a deeply engraved set of predisposition towards the segregation of humans and objects manifested in its treatment of the non-Western population. It is usually defined under the umbrella term of "slavery". Postcolonial studies have exposed the real agendas of "Enlightenment" that was activated with the "discovery" of the archipelagic islands of the Caribbean by Christopher Columbus. This proved to be a watershed moment for the human race; the enlightened class strengthened their economy and privilege employing exploitation and embezzlement, whereas the "primitive" mass faced severe dehumanizing process for centuries that left a permanent mark of marginality. The claim over land and human lives went hand-in-hand throughout the process of imperialism. Césaire has found the accurate equation, "colonization= 'thing-ification"" (Césaire, 1972, p. 6). 
Burgeoning business spurred the slave trade until a moral awakening at the end of the 1700s and the turn of the century saw rampant campaigns to abolish slavery. However, the 1833 Act could not stop human trafficking which was sustained under rhetoric terms such as "manumitted labour", "hired labour", "indenture labour", etc. In 1834, the chief magistrate in Calcutta wrote to acquaint the Secretary to Government about an agreement, whereby, a group of thirty-six hill coolies was indentured to work on a Mauritian sugar estate for a period of five years, with a guaranteed safe passage to and from Mauritius, a six-month advance pay of five rupees for men and four rupees for women along with a fixed ration and clothing on embarkation. Encouraged by positive reviews of the Mauritian indentureship, British Guiana permitted the enrolment of Indian labourers followed by the other British colonies. To steer clear of the accusations from the Anti-Slavery Societies due to the escalating number of abuses and abductions, a Government notice specified a preceding relation between the immigrant and arkati or local intermediary. As futile as this preventive measure sounds, it acted as an alibi against the unfair methods of human trafficking frequently resorted to by sirdars, arkatis, and local recruiters. The effect of indenture emigration was quite negligible compared to the slave trade as a large number of the indentees returned to the homeland after completing their contractual period with a substantial amount of money. Following the abolition, the labour movements in India were severely restricted and bifurcated to the Assam tea plantations and the jute mills of Bengal. This created a huge push in the homeland to stabilize the scales of demand and supply of labourers. The British Indian government saw this as an opportune moment to pass the law for indentured labourers to be immigrated to the British Caribbean islands by preposterously ignoring the fraudulent acts surrounding indentureship. In Ismith Khan's The Jumbie Bird, the protagonist, Kale Khan, and other ex-indentured labourers gather in a nearby Square every evening to smoke a pipe and reminisce over their past life. They would often make impassioned confessions of betrayal, since, "how we could ever know that when we come here they would give we cutlass and hoe to work in this hot sun? First day Mongroo get so much big, big blisters in his hands, he couldn't even hold the hoe the next mornin"' (Khan, 1961, p. 25). Nonetheless, the increasing demand for Indian labourers from the Caribbean plantations and the fairly positive outcome for all involved parties steamrolled the migration of indentured labourers from India to the Caribbean plantocracy.

Subsequently, there was a mass labour emigration between the years 1837 and 1917 from the Indian subcontinent to the Caribbean islands ensuing from the Slavery Abolition Act 1833 which became a potent mechanism in the formation of the Indo-Caribbean diaspora. The process begins with the intending migrant being approached by an arkati who usually functions as a provincial recruiter for recruiting agencies. The arkatis were perpetually on the outlook for naïve people in desperate need of work and were often accused of engaging in frauds and false promises. Indentees from unusual professional backgrounds - barbers, cooks, shopkeepers, dancers, writers, artists, gardeners, priests, soldiers, poultry and dairy farmers, blacksmith, etc. - in the early years of indentureship reveal the deceitful actions of the arkatis and complete disregard of the British officials towards the colonial subjects as a utility component. Gaiutra Bahadur makes a strong statement in Coolie Woman that "the British didn't recruit "coolies" for their sugar cane fields. Rather, they made "coolies"" (Bahadur, 2014, p. 43). Growing agitation from the Indians and regular complaints from the overseers and managers against the substandard workforce dispatched to their estate witnessed a drastic change in the entire operation of the system. From the 1880s onwards, a vast number of agriculture-based people were being recruited and a more stringent screening process was put in place. With the passing years, the norms of indenture became more transparent. Agencies faced frequent warnings from the government against their recruiters and they began hiring returned emigrants as recruiters who were trustworthy to their fellow countrymen as they became a microcosmic representation of a prosperous migrant community. Female ex-indentees were, particularly, induced to work as arkatis to encourage 
Indian women to work on Caribbean estates as there was a need to maintain a gendered ratio of emigrants. Gradually, the returned coolies were not only the best advocates for indentureship but also registered to be re-indentured and became diaspora Indians in the Indies. In fact, re-indentured coolies became poster-boys, first of all, because they acted as a manifestation of the success of the indenture project initiated by the British government against numerous odds; secondly, they were enormously productive for the estate managers due to their experience; and finally, the coolies were able to earn a small fortune and live generously upon their return to India. Several ex-indentees were able to acquire a small portion of land, usually a small section of infertile land, and settle in their adopted nation.

\subsection{Embodying the Girmit}

Peggy Mohan's Jahajin provides a comprehensive picture of the initial procedure of indentureship the recruitment, undertaking, embarkation, the kala pani odyssey, and the final assignment that shows the inhumane treatment of indentees as a mere commodity. The writer/narrator happens to be a linguist researching on Caribbean Bhojpuri who unravels the journey of Deeda, an indentured labourer aged over a hundred years, who migrated from the port of Calcutta to "chinidad", the land of sugar. Deeda, whose official name was Parbati, was a married woman with a son named Kalloo who took up the offer of indentureship since her husband left home for work many months ago and never looked back. When Deeda was surviving on the last few handfuls of rice grains with no hope of promising produce or the return of her husband, she came across an arkatiniya and "[s]he told me they were looking for women to go, and she promised me an extra advance if I signed up. Only one year there, she said, and then they bring you back. Plenty of money" (Mohan, 2007, p. 18). The potential recruits, mostly people wandering in search of work and shelter, were housed in a sub-depot by the recruiter. During their stay in the sub-depot, they had to go through a health inspection and interview before being registered by the local magistrate. The groups of indentees were brought to the Calcutta depot from various parts of the country where they are made aware of the terms and consequences of their undertaking by the Protector of Emigrants. Depot period proved to be a decisive period since many unsure indentees were swayed to journey on while many others withdrew or eloped. Agencies took up a more active role to persuade them and keep the indentees in good health till embarkation because they were the most priced commodities for the imperial government. Deeda relates that as soon as they reached the Khidderpore depot, each person was provided fresh clothing, a thin shawl, and a hot meal. While they are stationed at the depot, they undergo a final medical examination before being loaded on the ships. These despairing souls are acquainted with their new identity as a girmitiya. When Deeda overheard a strange word girmit and enquired the arkataniya about it, she said "[w]e would have to go in front of the magistrate and he would ask us if we understood what we would be signing up to do in Chini-dad and if we agreed to keep our side of the bargain" (Mohan, 2007, p. 20). However, the prolonged waiting period in the docks of Calcutta posed an issue for the recruiting agencies as many eloped as the consequences of crossing the kala pani dawned upon them while many more succumbed to the fatal blows of malaria, dengue, and cholera during their stay near the Ganges ghat.

Despite recent scholarship upholding pro-indenture dialectics, the indenture system had paltry positives in comparison to the slave trade. Following the seminal 1833 Act, the imperial government simply shifted radar from African colonies to Asian colonies to meet their labour demands that will keep their despotic machinery operative. The treatment of the colonial subjects as an exploitable workforce ready to be shipped off to places they are needed. The abolition act was undeniably revolutionary for the subaltern but the aftermath had little effect on the chronic commodification of the colonized people. The labours were one of the many commodities being transported through ships across the globe: 
It was monsoon, and the river was full of water, deeper. It was the best time to leave, they said. How every day they would bring more things to carry on the boat. Heaps of coal. Barrels of grease for the boat engines. Big, big barrels of water. All the things we would be eating: rice, dal, white flour, and dried saltfish. All in barrels, so that rats couldn't get at them. Potatoes, onions, pumpkin. Dried peas in jute sacks. Sugar and salt and masalas in jute sacks. Big, big pots to cook food for all the migrants, pots the size of barrels. Jute that they were carrying to sell in Trinidad. Buffaloes, goats. Fodder for the animals. Medicines. And new people had come, people who would go with us on the boat; bandhaaris, who would be the cooks, and masaalchis, cooks' assistants, bhangis to keep the boat clean. And laskars: stokers to shovel the coal for the boat engines and greasers to keep the engines covered with grease. (Mohan, 2007, p. 27)

Peggy Mohan's literary account is isomorphic of the reality of the indenture system and the dehumanized condition of the Indian labourers. Such acts of human objectification are a reflection of pre-existing social groups. Perhaps the ultimate practice of imperialism can be seen in the distribution of labour that promotes the Cartesian duality of the mind and the body. The study of the conjoined relationship between the subject and the object is the primary concern of material culture. Therefore, the relationship between the colonizer and the colonized becomes a predominant issue. The entire process of indenture was a discursive practice of pre-existing social distinctions and legitimized the commodification of the colonized people. During their journey, the labourers were made to walk on the decks with the animals, since, they all needed fresh air and movement to remain healthy and utilitarian. Labourers who were caught in mischief, theft, or contracted contagious diseases and/or died were fastened to an anchor and disposed of by throwing them into the waters, lest they infect the rest of the commodities. Once Deeda's ship docked at Nelson Island in the West Indies, they were given jute sacks to sit while they waited to be examined and fumigated. When the estate people arrived to inspect, Deeda's group was instantly selected, bought, and carried off to the estate. On their arrival to the estate, they were cautioned by the existing labourers to be careful of their overseers because "[s]ometimes they had trouble remembering that we were not their slaves" (Mohan, 2007, p. 117). Jan Shinebourne's The Last English Plantation remains true to its title and demonstrates the 1950s Guiana which is nothing different from the early plantation years. While June cycles to her new Anglican secondary school early in the morning on her first day, she witnesses the workers of the New Dam plantation waiting for instructions for the day's work from their foreman, an Indian, since, "overseers did not speak directly with a worker. They turned their backs on them and spoke amongst themselves, pausing only to deal with a foreman" (Shinebourne, 1988, p. 44). This fleeting vision seen by June is an everyday exercise that has been conducted throughout the entire duration of indenture and before that, in several repressive forms. This exposes the binary idealism of privileging the mind over the body which was an interminable phenomenon in the indenture system. Once again, the power play is strongly evident in the hierarchy of the overseers, foreman, and workers which evokes a Prospero-Ariel-Caliban relationship. This deeply entrenched socio-cultural hierarchy is inculcated from an impressionable age when Mrs. Farley, the eldest teacher at New Amsterdam School, liberally canes the coloured children from the plantation but never dares to raise her voice on the children whose parents are socially superior to her. Despite reformative changes and implementation of strict regulatory laws to facilitate better working conditions for the indentured labourers, most indentees experienced an acute degradation and frequently rose in rebellions against "British men who fought in the second world war... they still behaved as if they were in prison camps, only this time they were the ruling army and the sugar workers were the prisoners, that there was some kind of revenge or sickness in the way they overseered the plantation" (Shinebourne, 1988, p. 79). With the British government exercising severe torment on 
colonized India, registering as an indentured labourer further validated their sub-human status as from that moment onwards, they were completely at the mercy of their British masters. The illiterate and vulnerable people had no knowledge of the girmit they were legally bound by, the destination they were taken to or the kind labour they would have to perform; they had no psychological or corporeal grasp over their future. During her time on the upper-deck, Deeda often found herself outside the wheelhouse of the vessel fascinated to watch a white man steering the large wooden wheel and "think about how the whole boat and all of us were in that man's hands". (Mohan, 2007, p. 55)

\subsection{The Identity Question}

Shinebourne is able to give voice to the displaced community through the introspective dialogues of the feisty protagonist who becomes a spirited campaigner for the rights of coolies. On her first day at school, the headmaster's morning speech turns out to be coloured with colonial prejudice against African and Indian labourers, the mentally challenged, and people in correction homes. Though the headmaster, Mr. Singh, is of Indian origin, he considers the Indians belonging from an inferior social order as the "wretched of the earth" who deserve strict governing and dissociates himself from them. Mr. Singh's belief is centered on Fanonian mimicry that enables his ambivalent nature which June is quick is recognize and condemn: "He spoke as if labourers did not work hard, were labourers because they were laggards and idlers" (Shinebourne, 1988, p. 58). The hybrid environment of the Caribbean is rife with layers of ambivalence and "otherization". The most disfigured embodiment of cultural imperialism in The Last English Plantation is June's mother, Lucille. She is, now, a devout Anglican and feels hostile to her neighbours as well as her husband and daughter, who do not identify with Christianity. Lucille symbolizes perverse conditioning and enforces it upon her husband and on June, who is able to eschew the cultural cleansing. Her "epidermalization of inferiority" (Fanon, 1991, p. 62) can be heard when she spews curses at her own daughter to marry a coolie and remain a coolie woman. The identities of the descendants of the migrated indentees experience a paradigm shift from multicultural, integrationist to assimilative. We find these re-located girmits trying to facilitate a level of engagement with their ancestral culture vis-à-vis cultural appropriation with a diasporic consciousness.

Despite the stringent Hindu prohibition on crossing the kala pani which would lead to losing their caste and ousting from society according to orthodox Hindu belief, millions of Indians undertook the transoceanic journey. People from every stratum of Indian society enrolled for this labour trade, though the reasons differed; the untouchables, prostitutes, widows, runaway satis, fugitives and others of objectionable characters enrolled to escape further stigmatization; several single women, merchants, and peasants enlisted to earn a living in an economy controlled by Eurocentric authority. Unlike popular belief, a vast number of high caste people chose indentureship after losing business during frequent periods of droughts, famines, and prejudiced government policies. The colonial ploys seemed to have been the greatest sponsor for the indenture trade by creating convenient circumstances and regulating the movement of the population in the targeted colonies. The term "diaspora" has been used within the context of socio-cultural dislocation owing to modern capitalism, the colonial exile from one's native land to a place of uncertainty, giving birth to multiple forms of subjectivities. The exodus from the homeland is not only a corporeal displacement, rather a disruption of lifestyle, tradition, perspective, and systems of belief. The two French polymaths, Deleuze and Guattari explicate the concept of "rhizome" which fundamentally emphasizes multiplicity and heterogeneity, upholding the very crux of diasporic existence as they state "the rhizome connects any point to any other point, and its traits are not necessarily linked to traits of the same nature... It has neither a beginning nor end, but always a middle 
from it grows, and which it overspills... The rhizome is an antigenealogy" (Deleuze, 1987, p. 1). There is always a possibility of rupture or stagnation but being cultural anthropology, the rhizome will keep shifting and evolving to annex new territories. An engaging discourse is created out of their composite abode, amalgamating native and foreign cultures, which is ultimately a reflection of their own hybridized being.

The kala pani discourse has always been described as a transformative journey not only due to the Hindu tradition but owing to the brutal conditions on-board. The transatlantic migration has been a witness to a momentous catalyst in creating a global diaspora community that not only drastically altered individual lives but also initiated the remapping of the colonial and postcolonial cartography of the world map. The journey spanned over a period of three to four months passing through alarming tempests and chilly winds resulting in high mortality rates indicating that the life of a coolie is valued less than the drive of production. Amidst such despair, the coolies forged new relationships with the other jahajis. The concept of the jahaji-bhai or jahaji-bhain evokes a sense of shared bondage, cultural affinity, and spiritual fraternity initiated by the traumatic and perilous journey across the kala pani. This jahaji-hood consolidated the experience of dislocation, indentureship, and resettlement in an alien land. Peggy Mohan gives a detailed account of the "coolie odyssey" in Jahajin. The ship they were hoarded onto was overloaded with migrants from various parts of the country who were then compartmentalized, "[t]he single men's quarters were in the front of the boat, under the main deck, the married couples' quarters were behind that, and the single women's quarters were in the back, below the poop deck and the main deck" (Mohan, 2007 , p. 53). The emergence of women writers from the Indo-Caribbean sphere has led to the unfolding of a shared history of the transoceanic crossing by women from the global south space and how women formed clusters of mini-India in the foreign land. The understanding behind taking up a job that will lead to ostracism from one's family, a departure from their homeland, and undertaking the risk of a perilous voyage created a bond far stronger than the ones they left behind. One such instance is Deeda's narrative of a roaring storm at sea as she assists a jahaji-bhain to deliver her child as she constantly describes the labour pains with the upheaval of the sea waves: "And then, the last big wave and the long, long ride and the storm was over... [t] he little girl's head came first, and I reached in and freed her shoulder and she came out easily" (Mohan, 2007, 68). The storm is very obviously metaphorical, reflecting the confusion and anxiety within, and how they reach out to each other in the promise of an enduring connection throughout their indentureship and beyond. The usage of analogy between natural elements and human experiences is widely practiced by Indo-Caribbean women writers, as Shani Mootoo uses images of the natural world that reverberates the situation of the indentured labourers who made their journey from India, created a home in the tropical plantocracy, and decided not to make their passage back to the homeland. Mootoo's diasporic nature echoes in the words, "Snails, like most things in nature, have long memories. A snail's soul, which is invisible, mind you, will come back after it has died, looking for its old home". (Mootoo, 1996, p. 54)

In their book entitled Ecofeminism, Maria Mies and Vandana Shiva focus on the divergence of experiences of women in the postcolonial context from the Western ecofeminist ideas and identify women's freedom with "productive work in co-operation with Mother-Earth". Unfortunately, it has been difficult to appropriate Indo-Caribbean ecofeminism within the gamut of Western ecofeminism, since, the specific perspective of land and nature as communal and maternal entity differs drastically from Western Enlightenment practices. More importantly, the complex issue of a "pure" environment is completely inapposite in the hybrid and exogenous Caribbean milieu. The protagonist of Mootoo's novel Cereus Blooms at Night, Mala Ramchandin, suffers from a prolonged period of abuse from her father and abandonment by her sister and her mother who eloped with her lesbian lover. After killing her father in self-defence, Mala abandons his house, taking shelter 
in the garden, and gradually becomes a part of it, resembling the garden not just in appearance but also in its sound and smell. She emanated an earthly scent and her way of expression were sounds resembling the rare insects and birds which bred in the middle of the town, Lantanacamara. Belonging from the Indian indentured ancestry, Mala naturally forges a strange communion with the land which has been a prime factor throughout the Caribbean history of dispossession, torture, slavery, indentureship, and capitalist agendas. But for Mala the land is a symbol of love that transpired between her sister, her mother, and Lavinia, of hopes of being reunited with them in the future, of freedom from the oppressions of her father, and resistance against the norms of society.

\subsection{An Overview of the Life of the Indo-Caribbean Diaspora}

Khal Torabully, a Mauritian poet, film-maker, and cultural theorist, coined the term Coolitude playing on the word "negritude" that evokes a historical paradigm pointing at the subaltern position of the voyagers from Oceania to the European sugarcane colonies creating a crucible of Global South identities. Their odyssey has remained less valued owing to the lack of documentation which disregards the oral narratives of this jahajis. Torabully makes an unusual but not entirely inappropriate comparison between these indentured labourers and coral reefs as he says that the coral "maintains the egalitarian aspect of being together but is open to all currents. The coral is essentially a hybrid being, for it is born out of symbiosis... Even though it is rooted, it unleashes the greatest migration on Earth" (Marina and Torabully, 2002, p. 115). Though these immigrants have been severed from their parent domain, they are an extended part of their native land that organically modifies by retaining their cultural skeleton while forming new characteristics, as we find Deeda and a few other jahajis carrying seeds of local fruits and vegetables to sow in the foreign land, "Karailli! [Deeda exclaims] Here in Trinidiad! [w]ith a tone of surprise and joy] So we were not the first ones to think of bringing seeds from home [Deeda thinks]" (Mohan, 2007, p. 117). The corals, as we know, are a living symbiotic creature similar to the indentured Indo-Caribbean diaspora which has amassed for over a hundred years. They provide shelter to the water organisms and pool together to create coral ecosystems, just how diaspora communities forge relationships and stay affiliated as Deeda makes a makeshift family with five of her fellow voyagers and decides "[s]o we were going to keep together, the six of us... and hope they would send us together to the same estate" (Mohan, 2007, p. 91). Even though blood relations were not found, people recreated families with their jahaji and estate fellows, utilising the common cultural notions as a tool in the new land. The titular flower of the novel, cereus, is an exotic night-blooming flower blossom once a year for a short time and its fragrance pervades throughout the town of Lantanacamara, permeating the neighbouring households that ostracized Mala's existence for no fault of her own. As an act of rebellion, Mala also rejects conventional ways of living and takes permanent shelter in the wild garden of the house which was cultivated by her mother and symbolizes natural fecundity as opposed to the colonial patriarchal patterns of her father's house. Hence, the space of the garden becomes a "heterotopia" (Foucault, 1986) reminiscent of the blissful days spent with her mother, sister, and Aunt Lavinia while inside the premises of the house they lived in constant fear of Chandin's abuse. These diaspora characters oscillate between two extremes, one trapped in nostalgia, the other that thrives in plurality and demolishes the genealogy. In a way, they are rhizomatic by not being a mere imitation of a prototype, since a rhizome is "a map and not a tracing”.

Though the Caribbean islands have been utilised for various imperial programmes, it became a symbolic interstitial site for cultural discourse. An array of races, cultures, and nationality of every denomination, in a struggle to thrive and overpower one another, amalgamates and favourably co-exist in the island nation. Despite the plurality, the Caribbean 
has retained a single identity that has encompassed the African, the Indian, the Chinese, the White, the Christian, the Hindu, the Muslim, and others. Despite numerous languages that escorted the various cultures, the lingua franca has remained English, the language left behind by the colonial masters and creolized over time. This multiplicity creates a phenomenon of "othering" where the citizens have to constantly negotiate their individual identity, producing a space of "in-betweenness" which is comprehensively captured and reproduced by the writers/artists through their works. This intermediate space often leads to the distortion of normative paradigms of society and it is in this space that the allegiances and transgressions become evident and acceptable. The demarcations of prescriptive patterns laid out by society become indistinct amidst the constant tussle to remain rooted to their native culture and find their individuality against the intersecting culture and nationality. This threshold offers a space of expression for the non-normative, the unrepresented, and the marginalised.

\section{References}

Ashcroft, Bill. (1998). Key Concepts in Postcolonial Studies. Routledge.

Ashcroft, Bill. \& Tiffin, Helen. \& Griffiths, Gareth. (2002). The empire writes back : theory and practice in post-colonial literatures. Routledge.

Bahadur, Gaiutra. (2014). Coolie Woman. The University of Chicago Press.

Bhabha, Homi. (1990). Identity: Community, Culture, Difference. Lawrence \& Wishart.

Bhabha, Homi. (1994). The Location of Culture. Routledge.

Bragard, Véronique. (2008). Transoceanic Dialogues: Coolitude in Caribbean and Indian Ocean Literature. P.I.E. Peter Lang.

Byron, Margaret, Stephanie Condon. (2008). Migration in Comparative Perspective: Caribbean Communities in Britain and France. Routledge.

Carter, Marina, and Khal Torabully. (2002). Coolitude: An Anthology of the Indian Labour Diaspora. Wimbledon Publishing House.

Césaire, Aimé. (1972). Discourse on Colonialism (Joan Pinkham, Trans.). Monthly Review Press. (Original work published 1950).

Clifford, James. (1997). Routes: Travel and Translation in the Late Twentieth Century. Harvard.

Deb, Nilanjana. (2017). (Re)moving Bodies: People, Ships and Other Commodities in the Coolie Trade from Calcutta. In Supriya Chaudhuri (Ed.), Commodities and Culture in the Colonial World (Intersections: Colonial and Postcolonial Histories. Routledge.

Deleuze, Gilles, Felix Guattari. (1987). A Thousand Plateaus: Capitalism and Schizophrenia. The University of Minnesota Press.

Fanon, Frantz. (1991). Black Skin, White Masks. Grove Weidenfeld.

Foucault, Michel. (1986). "Of Other Spaces”. Diacritics, No. 16, 22-27.

Gilroy, Paul. (1993). The Black Atlantic. Harvard University Press.

Gumilev, L.N. (1993). Ethnogenesis and the Biosphere of the Earth. Michelle and Co.

Khan, Ismith. (1961). The Jumbie Bird. Macgibbon \& Kee.

Kopytoff, Igor. (1986). The Cultural Biography of Things: Commoditization as a Process. Arjun Appadurai (Ed.), The Social Life of Things: Commodities in Progress, pp. 6491. Cambridge University Press.

Mies, Maria, and Vandana, Shiva. (1993). Ecofeminism. Fernwood Publications.

Mohan, Peggy. (2007). Jahajin. Harper Collins.

Mootoo, Shani. (1996). Cereus Blooms at Night. Grove Press.

Northrup, David. (1995). Indentured Labor in the Age of Imperialism 1834-1922. Cambridge University Press.

Shinebourne, Janice. (2011). The Last English Plantation. Peepal Tree Press. 
Tilley, C., Keane, W., Küchler, S., Rowlands, M., \& Spyer, P. (2006). Handbook of material culture. SAGE Publications Ltd. https://www.doi.org/10.4135/9781848607972

Tinker, Hugh. (1974). A New System of Slavery: the Export of Indian Labour Overseas. Oxford University Press.

Younger, Paul. (2010). New Homelands: Hindu Communities in Mauritius, Guyana, Trinidad, South Africa and East Africa. Oxford University Press.

\section{Bio-note}

Shehnaz Kabir is a Senior Research Scholar in the Department of English, Jadavpur University. She has completed her Bachelor and Master of Arts from the University of Calcutta. Her topic of research is "Indentured Diaspora in Indo-Caribbean Literature", and has also written a M.A. dissertation on the tropes of sexuality in select short stories of JhumpaLahiri. Her areas of interest lies in Diaspora Studies, Postcolonial Literary Theory and Indenture Labour trade.

Email Id: kabirshehnaz@gmail.com 